\title{
Analisa Kualitas Website Menggunakan Metode Webqual 4.0 (Studi Kasus: Badan Kepegawaian Daerah Provinsi Riau)
}

\author{
${ }^{1}$ Nurmaini Dalimunthe, ${ }^{2}$ Tricia Karina, ${ }^{3}$ Arabiatul Adawiyah \\ ${ }^{1,2,3}$ Program Studi Sistem Informasi, Fakultas Sains dan Teknologi UIN Suska Riau \\ Jl. HR Soebrantas KM.18 Panam Pekanbaru - Riau \\ Email: ${ }^{1}$ nurmaini.dalimunthe@uin-suska.ac.id, ${ }^{2}$ tricia.karina@students.uin-suska.ac.id, \\ 3adawiyaharabiatul@gmail.com
}

\begin{abstract}
ABSTRAK
Website badan kepegawaian daerah provinsi riau telah memanfaatkan website dalam pelayanan publik. Selama dipublikasikan masih terdapat masalah dari segi kualitas kegunaan seperti fitur pada menu bar tidak berfungsi dengan baik, dari kualitas informasi ditemukan adanya tampilan error pada masingmasing informasi mengenai badan kepegawaian daerah perkabupaten yang ada di provinsi riau dan dari kualitas interaksi pelayanan tidak adanya pemberitahuan kesalahan pada saat input data pada email. Dalam penelitian ini, kualitas website badan kepegawaian daerah provinsi riau diukur dengan menggunakan metode Webqual 4.0 dengan analisis regresi linear berganda. Hasil dari penelitian ini adalah bahwa website ini sudah memuaskan pegawai, berdasarkan diterima dua hipotesis yang diajukan yaitu hipotesis kualitas kegunaan dan kualitas informasi dengan kontribusi variabel terhadap kepuasan sebesar 52,3\%. Adapun hasil hipotesis dari penelitian ini adalah diterimanya atau berpengaruhnya dua variabel dari tiga variabel yang digunakan dalam penelitian ini yaitu, kualitas kegunaan dan kualitas informasi terhadap kepuasan pengguna. Diterimanya kedua variabel tersebut menandakan bahwa kualitas kegunaan Badan Kepegawaian Daerah Provinsi Riau sudah sesuai dengan yang diinginkan pegawai, seperti situs website mudah dipelajari, jelas, dan tepat dalam penyusunan tata letak informasi, dan kualitas informasi juga sudah sesuai dengan kepuasaan pegawai, seperti informasinya diberikan jelas, up to date, dan dalam format yang sesuai. Adapun satu hipotesis ditolak yaitu kualitas interaksi pelayanan menandakan bahwa pegawai belum merasa aman, tidak melindungi privasi pegawai, dan tidak yakin dengan informasi yang diberikan.
\end{abstract}

Kata kunci : regresi linear berganda, webqual 4.0, website

\section{A. PENDAHULUAN}

Teknologi informasi dan komunikasi (TIK) merupakan salah satu teknologi yang berkembang dengan sangat pesat. Berbagai keuntungan teknologi informasi khususnya internet banyak diterapkan dalam kehidupan manusia termasuk dibidang pemerintahan. Pemerintahan Indonesia telah membuat kebijakan untuk memanfaatkan TIK, mulai dari tingkat pemerintah daerah hingga kepusat[5]. Website merupakan salah satu media yang disediakan melalui jalur internet dimana pengguna dapat mengakses semua jenis informasi dimanapun dan kapanpun selama terkoneksi dengan jaringan internet. Saat ini hampir seluruh instansi pemerintah menggunakan website sebagai salah satu bentuk pelayanan informasi kepada seluruh pegawai. Website sangatlah penting dalam segala bidang terutama untuk sebuah organisasi ataupun perusahaan. Website juga sudah menjadi bagian penting dari organisasi nirlaba termasuk juga instansi pemerintahan[3]. Peranan website untuk instansi pemerintahan sudah menjadi salah satu bagian penting bagi instansi tersebut termasuk juga bagi badan kepegawaian daerah provinsi riau.

Badan Kepegawaian Daerah Provinsi Riau (BKD) telah memanfaatkan website dalam pelayanan publik, Website (BKD) Provinsi Riau yang beralamatkan di bkd.riau.go.id. Website Badan Kepegawaian Daerah Provinsi Riau di publikasikan pada tahun 2011 berfungsi untuk memberikan informasi mengenai kinerja organisasi Badan Kepegawaian Daerah Provinsi Riau, untuk mempublikasikan data-data, sebagai media informasi bagi pengguna internal (pegawai) yang membutuhkan data dan informasi.

Berdasarkan hasil observasi dan wawancara dengan pengelola website diakuinya masih terdapat kelemahan-kelemahan pada website Badan Kepegawaian Daerah Provinsi Riau. Permasalahan pertama yaitu pada menu 
bar profil, informasi, pengadaan, pendidikan dan pelatihan, mutasi, dan cuti. Pada setiap masing-masing sub menu ada beberapa sub menu jika diklik terdapat informasi yang tidak sesuai. Terdapat teks dalam bahasa inggris dan tidak ada kaitannya dengan informasi tentang profil, informasi, pengadaan, pendidikan dan pelatihan, mutasi, dan cuti. Akibatnya pegawai dan pengunjung situs website mengalami kekurangan informasi.

Permasalahan berikutnya yaitu di bagian bawah halaman website, dimana terdapat subsub menu BKD kab. Indragiri Hilir, BKD kab.Kepulauan Meranti, BKD kab. Kuantan Singingi, BKD kab. Pelalawan, BKD kab. Siak, dan BKD kota Dumai. Jika diklik menampilkan tampilan error dan belum ada berisi data didalam nya. Akibatnya pengunjung situs website tidak bisa mendapatkan informasi pada masing-masing kabupaten yang ada di Provinsi Riau.

Permasalahan lainnya adalah pada saat ingin memasukkan data pada kirim pesan ke BKD, data E-mail bisa diisi secara bebas dan tanpa adanya pemberitahuan kesalahan saat mengisi data, dan data tetap bisa dikirim. Hal ini tentunya membuat data-data pengguna tidak aman.

Untuk mengatasi masalah-masalah di atas, perlu dilakukan analisa untuk melihat sejauh mana kualitas website telah dapat berfungsi dengan baik sesuai dengan keinginan pengguna. Untuk mengukur kualitas website berdasarkan persepsi pengguna akhir maka digunakan metode WebQual 4.0[10]. Metode Webqual 4.0 ini adalah untuk menentukan kualitas website. Metode ini terdiri atas 3 tahapan dalam menentukan kualitas website yaitu kegunaan/kemudahan (usability), kualitas informasi (information quality), dan kualitas interaksi pelayanan (service interaction quality)[9]. Sehingga dengan pengukuran 3 tahapan tersebut dapat memberikan informasi yang akurat dan memberikan penilaian terhadap kelayakan website. Webqual pada dasarnya mengukur mutu sebuah web berdasarkan persepsi dari pengguna atau pengunjung situs. Jadi pengukurannya menggunakan instrument penelitian atau kuesioner.

Wahidin Abbas (2013) dalam penelitiannya tentang kepuasan mahasiswa terhadap website UNY menghasilkan bahwa nilai usabilitynya sebesar 2,78, information quality sebesar 2,86 dan nilai interaction quality sebesar 2,75 dengan total akhir 2,8 yang berarti bahwa mahasiswa merasa puas terhadap website tersebut.
Berdasarkan penjelasan diatas, maka diangkat suatu penelitian dengan judul Analisa Kualitas Website Dengan Menggunakan Metode Webqual 4.0 (Studi Kasus : Badan Kepegawaian Daerah Provinsi Riau).

\section{B. LANDASAN TEORI}

\section{B.1. Website}

Website disebut juga site, situs, situs web atau portal. Merupakan kumpulan halaman web yang berhubungan antara satu dengan lainnya, halaman pertama sebuah website adalah home page, sedangkan halaman demi halamannya secara mandiri disebut web page, dengan kata lain website adalah situs yang dapat diakses dan dilihat oleh para pengguna internet diseluruh dunia. Website adalah situs yang dapat diakses dan dilihat oleh para pengguna Internet. Pengguna Internet semakin hari semakin bertambah banyak, sehingga hal ini adalah potensi pasar yang berkembang terus[1].

\section{B.2. Kualitas Informasi Website}

Kualitas informasi mengukur kualitas keluaran dari sistem informasi. mengembangkan enam item pertanyaan untuk mengukur kepentingan persepsi dan kebergunaan informasi dari informasi yang disajikan dan laporan-laporan yang dihasilkan oleh sistem informasi tersebut. Seperti pengukuran isi web harus personal, lengkap relevan, mudah di pahami dan aman. Indikator yang diukur meliputi :

1) Kelengkapan (completeness)

2) Ketepatan (precission)

3) Akurasi (accuracy)

4) Keandalan (reliability)

5) Kekinian (currency)

6) Bentuk Keluaran (format of output)

Pengukuran-pengukuran kualitas informasi diatas merupakan hasil penelitian Delone dan McLean dan sudah terbukti keakuratannya dalam melakukan pengukuran terhadap sistem informasi yang di bangun[8].

\section{B.3. Webqual}

Webqual merupakan pengembangan dari SERVQUAL yang banyak digunakan sebelumnya pada pengukuran kualitas jasa.Webqual adalah metode yang digunakan dalam mengukur kualitas suatu website berdasarkan persepsi pengguna akhir website tersebut.Metode ini sudah digunakan sejak tahun 1998 yang dimulai dari webqual 1.0 sampai saat ini webqual 4.0[7].

Instrumen WebQual menggunakan pendekatan perception dan importance dari pengguna. Jika WebQual 1.0 menitikberatkan analisa kualitas informasi dan memiliki 
kekurangan di interaksi layanan, WebQual 2.0 sebaliknya, yaitu lebih menekankan pada analisa terhadap interaksi tetapi terasa kurang pada analisa kualitas informasi. Kedua instrumen tersebut dicoba untuk diterapkan pada sebuah penelitian terhadap kualitas situs lelang online[4]. Hasil penelitian tersebut menunjukkan bahwa kualitas situs terbagi atas kualitas situs, kualitas informasi yang disediakan dan kualitas interaksi yang ditawarkan oleh layanan. Hasil penelitian inilah yang dikenal sebagai WebQual 3.0. Analisa lanjutan terhadap WebQual 3.0 menghasilkan pendekatan model WebQual 4.0 yang akhirnya mengganti dimensi pertama, yaitu kualitas situs menjadi dimensi Usability (Kegunaan).

Penelitian ini menggunakan model WebQual 4.0 dan disusun berdasarkan tiga area yakni kemudahanPenggunaan (usability), kualitas informasi (information quality) dan kualitas interaksi (interaction quality)[4].

\section{B.4. Badan Kepegawaian Daerah Provinsi Riau \\ Badan Kepegawaian Daerah (BKD)}

Provinsi Riau di bentuk dengan Peraturan Daerah Provinsi Riau Nomor 03 Tahun 2014 tentang Organisasi dan Tata Kerja Inspektorat, Badan Perencanaan Pembangunan Daerah dan Lembaga Teknis Daerah Provinsi Riau, yang tertuang dalam pasal 56 Peraturan Daerah ini tentang Pembentukan Badan Kepegawaian Daerah Provinsi Riau yang isinya yaitu :

1. Badan Kepegawaian Daerah merupakan unsur penunjang tugas tertentu Pemerintah Provinsi Riau;

2. Badan Kepegawaian Daerah dipimpin oleh seorang Kepala Badan yang berada dibawah dan bertanggung jawab kepada Gubernur melalui Sekretaris Daerah;

Dalam pasal 56 Peraturan Daerah di atas, Badan Kepegawaian Daerah mempunyai tugas dan fungsi dalam pelaksanaan penyusunan dan pelaksanaan kebijakan daerah bidang kepegawaian daerah serta dapat ditugaskan untuk melaksanakan penyelenggaraan wewenang yang dilimpahkan oleh Pemerintah kepada Gubernur selaku Wakil Pemerintah dalam rangka dekosentrasi.

\section{METODOLOGI PENELITIAN}

Adapun proses dalam melakukan penelitian ini adalah sebagai berikut:

\section{C.1. Pendahuluan}

Pada tahapan pendahuluan ini kegiatan yang dilakukan adalah : (1) Menentukan Tempat Penelitian; (2) Menentukan Objek
Penelitian; dan (3) Menentukan Judul

Penelitian.

\section{C.2. Perencanaan}

Adapun tahapan dalam perencanaan adalah sebagai berikut: (1) Identifikasi Masalah; (2) Menentukan Data Yang dibutuhkan; (3) Menentukan Hipotesis; (4) Menentukan Responden; dan (5) Studi pustaka.

\section{C.3. Pengumpulan Data}

Pada tahap pengumpulan data yang dilakukan adalah : (1) Observasi; (2) Wawancara; dan (3) Menyebarkan Kuesioner.

\section{C.4. Pengolahan Data}

Pada tahapan pengolahan data yang dilakukan mengolah data dengan uji validasi dan uji reliabilitas.

\section{C.5. Analisa dan Pembahasan}

Adapun tahapan dalam analisa ini adalah :

(1) Deskripsi tanggapan terhadap variabel penelitian; (2) Uji asumsi klasik; (3) Uji regresi linear berganda; dan (4)uji hipotesis.

\section{C.6. Penulisan Laporan}

melakukan dokumentasi hasil penelitian tugas akhir yaitu seluruh data yang diperoleh dari serangkaian penelitian yang telah dilakukan akan menghasilkan sebuah laporan yang nantinya akan diujikan kembali kepada pembimbing ataupun penguji penelitian.

\section{ANALISA DAN PEMBAHASAN \\ D.1 Uji Validitas}

penelitian dilakukan dengan menghitung angka korelasi atau $r$ hitung dari nilai jawaban tiap responden untuk tiap butir pertanyaan, kemudian dibandingkan dengan $r$ tabel. Nilai $r$ tabel diperoleh dengan persamaan $\mathrm{N}-2=62-2$ $=60=0,25$. Tingkat signifikansi 5\%, maka didapat $r$ tabel 0,25 . Setiap butir pertanyaan dikatakan valid jika $r$ hitung $>r$ tabel dan nilai positif maka butir atau pertanyaan atau indikator tersebut dinyatakan valid[6].

Tabel 1. Uji Validitas

\begin{tabular}{cccc}
\hline Pernyataan & $\mathbf{r}_{\mathbf{x y}}$ & $\begin{array}{c}\mathbf{r}- \\
\text { tabel }\end{array}$ & Keterangan \\
\hline P1 & 0,598 & & Valid \\
P2 & 0,583 & & Valid \\
P3 & 0,602 & & Valid \\
P4 & 0,423 & 0,25 & Valid \\
P5 & 0,483 & & Valid \\
P6 & 0,623 & & Valid \\
P7 & 0,554 & & Valid \\
P8 & 0,667 & & Valid \\
P9 & 0,407 & & Valid \\
P10 & 0,631 & 0,25 & Valid \\
P11 & 0,603 & & Valid \\
P12 & 0,481 & & Valid
\end{tabular}




$\begin{array}{llll}\text { P13 } & 0,657 & \text { Valid } \\ \text { P14 } & 0,748 & \text { Valid } \\ \text { P15 } & 0,574 & \text { Valid } \\ \text { P16 } & 0,372 & & \text { Valid } \\ \text { P17 } & 0,675 & & \text { Valid } \\ \text { P18 } & 0,570 & 0,25 & \text { Valid } \\ \text { P19 } & 0,458 & & \text { Valid } \\ \text { P20 } & 0,376 & & \text { Valid } \\ \text { P21 } & 0,464 & \text { Valid }\end{array}$

Tabel diatas menunjukkan bahwa nilai $r$ hitung untuk masing-masing pernyataan kualitas kegunanaan website yang ada di Kantor Badan Kepegawaian Daerah Provinsi Riau adalah berkisar antara $(0,423)$ sampai $(0,623)$, r hitung untuk masing-masing pernyataan kualitas informasi website yang ada di Kantor Badan Kepegawaian Daerah Provinsi Riau adalah berkisar antara $(0,407)$ sampai $(0,748)$, dan $r$ hitung untuk masing-masing pernyataan kualitas interaksi layanan website yang ada di Kantor Badan Kepegawaian Daerah Provinsi Riau adalah berkisar antara $(0,372)$ sampai $(0,675)$. Hasil uji Semua nilai $r$ hitung untuk masingmasing pernyataan lebih besar dari $r$ tabel $(0,25)$. Hal ini berarti bahwa setiap butir pertanyaan dalam penelitian ini adalah valid.

\section{D.2 Uji Reliabilitas}

Berdasarkan hasil uji reliabilitas menunjukkan bahwa koefisien reliabilitas kualitas kegunanaan website yang ada di Kantor Badan Kepegawaian Daerah Provinsi Riau sebesar 0,803 yang menunjukkan bahwa koefisien Cronbach Alpha lebih besar dari 0,6 sehingga dapat disimpulkan bahwa data kualitas kegunanaan website yang ada di Kantor Badan Kepegawaian Daerah Provinsi Riau dalam penelitian ini adalah reliabel. Koefisien reliabilitas kualitas informasi website yang ada di Kantor Badan Kepegawaian Daerah Provinsi Riau adalah sebesar 0,837 lebih besar dari nilai kritis yang berarti data kualitas informasi website yang ada di Kantor Badan Kepegawaian Daerah Provinsi Riau reliabel. Dan koefisien reliabilitas kualitas interaksi layanan website yang ada di Kantor Badan Kepegawaian Daerah Provinsi Riau adalah sebesar 0,771 lebih besar dari nilai kritis yang berarti data kualitas interaksi layanan website yang ada di Kantor Badan Kepegawaian Daerah Provinsi Riau reliabel untuk dilakukan uji tahap berikutnya.

\section{D.3 Uji Asumsi Klasik} Uji Normalitas Data

Tabel 2. Uji normalitas (Kolmogorov Smirnov) One-Sample Kolmogorov-Smirnov Test

Unstandardize d Residual

\begin{tabular}{llr}
\hline $\mathrm{N}$ & & 62 \\
Normal & Mean &, 0000000 \\
Parameters $^{\mathrm{a}, \mathrm{b}}$ & Std. &, 52849601 \\
& Deviation & \\
Most Extreme & Absolute &, 088 \\
Differences & Positive &, 077 \\
& Negative &,- 088 \\
Test Statistic & &, 088 \\
Asymp. Sig. (2-tailed) &, $200^{\mathrm{c}, \mathrm{d}}$ \\
\hline
\end{tabular}

hasil uji normalitas di atas, dapat terlihat bahwa nilai signifikansi untuk semua persamaan regresi sebesar 0,200 lebih besar dari 0,05. Hal ini menyatakan bahwa model regresi memenuhi asumsi normalitas.

\section{Uji Multikolinearitas}

Tabel 3. Hasil Uji Multikolonierita

\begin{tabular}{|c|c|c|c|}
\hline \multirow{2}{*}{$\begin{array}{c}\text { Variabe } \\
1\end{array}$} & \multicolumn{2}{|c|}{$\begin{array}{c}\text { Collinearity } \\
\text { Statistics }\end{array}$} & \multirow{2}{*}{ Keterangan } \\
\hline & $\begin{array}{c}\text { Toleranc } \\
\mathrm{e}\end{array}$ & VIF & \\
\hline $\mathrm{X} 1$ & 0,549 & 1,822 & $\begin{array}{l}\text { Tidak terdapat } \\
\text { Multikolonierita } \\
\text { s }\end{array}$ \\
\hline $\mathrm{X} 2$ & 0,535 & 1,868 & $\begin{array}{l}\text { Tidak terdapat } \\
\text { Multikolonierita } \\
\text { s }\end{array}$ \\
\hline X3 & 0,935 & 1,069 & $\begin{array}{l}\text { Tidak terdapat } \\
\text { Multikolonierita } \\
\text { s }\end{array}$ \\
\hline \multicolumn{4}{|c|}{$\begin{array}{l}\text { Dari tabel } 3 \text { dapat dilihat bahwa nilai } \\
0 \text { untuk semua variabel bebas, begitu } \\
\text { ngan nilai tolerance > } 0,10 \text {. Dengan } \\
\text { dapat disimpulkan bahwa tidak ada } \\
\text { multikolinearitas antara variabel bebas } \\
\text { nelitian ini. }\end{array}$} \\
\hline
\end{tabular}

Uji Heteroskedastisitas

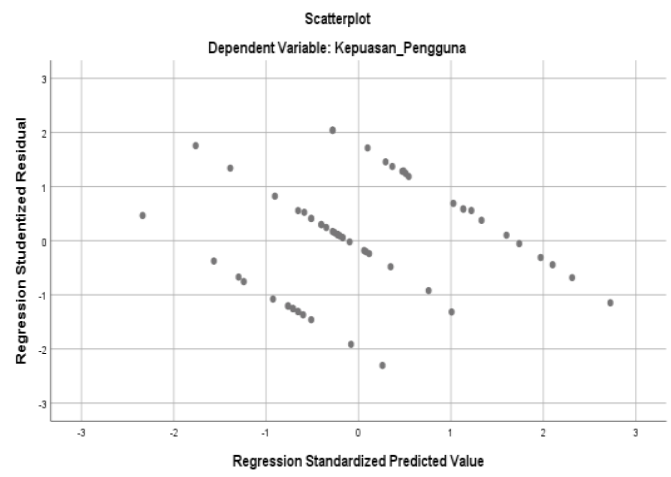

Gambar 1. Hasil Uji Heteroskedastisitas

Dari gambar diatas didapatkan bahwa data menyebar tidak membentuk pola-pola tertentu yang teratur (bergelombang, melebar kemudian 
menyempit), sehingga dapat disimpulkan bahwa model dalam penelitian ini tidak terdapat heterodeksitas.

\section{Uji Autokorelasi}

Berdasarkan uji Durbin Watson (DW) yang telah dilakukan, diketahui nilai DW dihasilkan model regresi yaitu sebesar 2,116. Sedangkan untuk nilai tabel DW dengan sampael $\mathrm{N}=62$ dan variabel indevendennya $(\mathrm{k})=3$ diperoleh nilai $\mathrm{dL}=1.480$ dan $\mathrm{dU}=1.689$. Karena hasil uji autokorelasi menunjukkan nilai DW lebih besar dari nilai dU dan lebih kecil dari 4-dU atau $\mathrm{dU}<\mathrm{d}<4$-dU. Maka dapat disimpulkan dalam penelitian ini dapat memenuhi asumsi yaitu tidak terdapat autokorelasi positif atau negatif.

\section{D.4 Uji Regresi Linear Berganda}

Penggunaan teknik analisis data regresi berganda untuk mencari pengaruh antara variabel bebas yaitu kualitas kegunaan (X1), kualitas informasi (X2) dan kualitas interaksi layanan (X3) terhadap variabel terikat yaitu kepuasan pengguna website yang ada di Kantor Badan Kepegawaian Daerah Provinsi Riau (Y).

\section{Model Persamaan Regresi Linear Berganda}

$\mathrm{Y}=\mathrm{a}+\mathrm{b}_{1} \mathrm{X}_{1}+\mathrm{b}_{2} \mathrm{X}_{2}+\mathrm{b}_{3} \mathrm{X}_{3}+\mathrm{e}$

$Y=-2,253+0,109 X_{1}+0,159 X_{2}-0,030 X_{3}+e$

Arti angka-angka dalam persamaan regresi diatas:

- Nilai konstanta (a) sebesar (-2,253). Artinya adalah apabila variabel independen diasumsikan nol (0), maka nilai kepuasan pengguna website yang ada di Kantor BKD Provinsi Riau adalah sebesar $(-2,253)$.

- Nilai koefisien regresi variabel kualitas kegunaan website yang ada di Kantor BKD Provinsi Riau adalah sebesar 0,109. Artinya adalah bahwa setiap peningkatan nilai kualitas kegunaan website yang ada di Kantor BKD Provinsi Riau sebesar 1 satuan maka akan meningkatkan nilai kepuasan pengguna website yang ada di Kantor BKD Provinsi Riau sebesar 0,109 dengan asumsi variabel lain tetap.

- Nilai koefisien regresi variabel kualitas informasi website yang ada di Kantor BKD Provinsi Riau adalah sebesar 0,159. Artinya adalah bahwa setiap peningkatan nilai kualitas informasi website yang ada di Kantor BKD Provinsi Riau sebesar 1 satuan maka akan meningkatkan nilai kepuasan pengguna website yang ada di Kantor BKD Provinsi Riau sebesar 0,159 dengan asumsi variabel lain tetap.

- Nilai koefisien regresi variabel kualitas interaksi layanan website yang ada di Kantor BKD Provinsi Riau adalah sebesar $(-0,030)$. Artinya adalah bahwa setiap peningkatan nilai kualitas interaksi layanan website yang ada di Kantor BKD Provinsi Riau sebesar 1 satuan maka akan menurunkan nilai kepuasan pengguna website yang ada di Kantor BKD Provinsi Riau sebesar 0,030 dengan asumsi variabel lain tetap.

Standar error (e) merupakan variabel acak dan mempunyai distribusi probabilitas yang mewakili semua faktor yang mempunyai pengaruh terhadap $\mathrm{Y}$ tetapi tidak dimasukan dalam persamaan.

Uji Korelasi dan Determinasi

Tabel 4. Koefisien determinasi

Model Summary ${ }^{b}$

\begin{tabular}{|c|c|c|c|c|}
\hline 100 & $\mathrm{R}$ & $\begin{array}{c}\mathrm{R} \\
\text { Square }\end{array}$ & $\begin{array}{c}\text { Adjusted } \\
\text { R } \\
\text { Square }\end{array}$ & $\begin{array}{c}\text { Std. } \\
\text { Error of } \\
\text { the } \\
\text { Estimate }\end{array}$ \\
\hline 1 &, $723^{a}$ &, 523 & 499 & ,542 \\
\hline
\end{tabular}

Berdasarkan tabel diatas, diketahui nilai $\mathrm{R}$ Square sebesar 0,523. Artinya adalah bahwa sumbangan pengaruh variabel independen terhadap variabel dependen adalah sebesar $52,3 \%$. Sedangkan sisanya $57,7 \%$ dipengaruhi oleh variabel lain yang tidak dimasukkan dalam model regresi ini.

\section{D.5. Pengujian Hipotesis}

1. Uji F

Tabel 5. Analisis Variansi, Anova

ANOVA $^{\text {a }}$

\begin{tabular}{|c|c|c|c|c|c|}
\hline \multirow[b]{2}{*}{ Model } & \multicolumn{5}{|c|}{$\begin{array}{c}\text { Mea } \\
\text { n } \\
\text { Squa }\end{array}$} \\
\hline & $\mathrm{s}$ & Df & re & $\mathrm{F}$ & Sig. \\
\hline $\begin{array}{l}\text { Regres } \\
\text { sion }\end{array}$ & 18,704 & 3 & $\begin{array}{r}6,23 \\
5\end{array}$ & 21,224 &, $000^{b}$ \\
\hline $\begin{array}{l}\text { Residu } \\
\text { al }\end{array}$ & 17,038 & 58 & ,294 & & \\
\hline Total & 35,742 & 61 & & & \\
\hline
\end{tabular}

Pada tabel diatas, ternyata didapat $\mathrm{F}_{\text {hitung }}$ adalah sebesar 21,224 dengan probabilitas 0,000, sedangkan $F_{\text {tabel }} 2,76$ dengan tingkat signifikan (alpha) 5\%. Jadi dapat disimpulkan bahwa $F_{\text {hitung }}=21,224>2,76$. Dengan demikian kualitas kegunaan (X1), kualitas informasi (X2) dan kualitas interaksi layanan (X3) website yang ada di Kantor BKD Provinsi Riau secara bersama-sama berpengaruh signifikan terhadap kepuasan pengguna website yang ada di Kantor BKD Provinsi Riau.

2. Uji T 
Uji t bertujuan untuk menguji seberapa jauh pengaruh satu variabel independen secara individual dalam menerangkan variabel dependen. Untuk dapat mengetahui apakah ada pengaruh yang signifikan dari masing-masing variabel independen, maka dibandingkan antara nilai $t_{\text {hitung }}$ dengan $t_{\text {tabel }}$ serta membandingkan nilai signifikan t dengan level of significant $(\alpha)$. Nilai dari level of significant yang digunakan dalam penelitian ini adalah 5 persen $(0,05)$. Apabila sig $t$ lebih besar dari 0,05 maka $\mathrm{H}_{0}$ diterima. Demikian pula sebaliknya jika sig $\mathrm{t}$ lebih kecil dari 0,05, maka $\mathrm{H}_{0}$ ditolak[9].

Tabel 6. Uji T

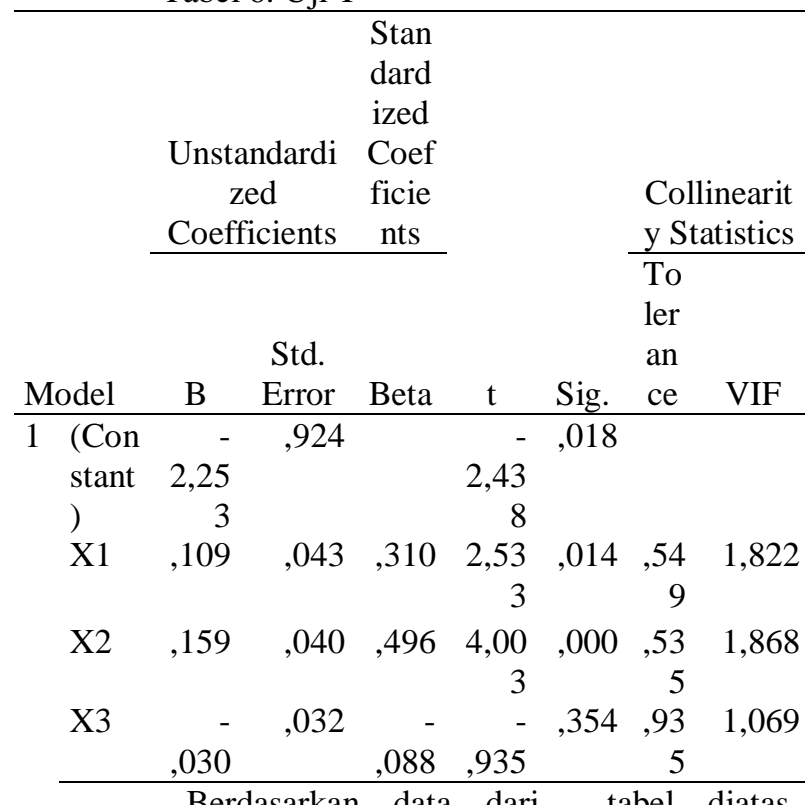

Berdasarkan data dari tabel diatas diketahui nilai $t_{\text {tabel }}$ pada taraf signifikasi $5 \%$ dengan persamaan sebagai berikut:

$$
\begin{aligned}
\mathrm{t}_{\text {tabel }} & =\mathrm{n}-\mathrm{k}-1: \text { alpha/2 } \\
& =62-3-1: 0,05 / 2 \\
& =58: 0,025 \\
& =2,002 /-2,002
\end{aligned}
$$

a. Variabel Kualitas Kegunaan

Hipotesis variabel kualitas kegunaan adalah: Ho : Variabel kualitas kegunaan tidak berpengaruh signifikan/positif terhadap kepuasan pengguna website yang ada di BKD Provinsi Riau.

$\mathrm{H}_{1}$ : Variabel kualitas kegunaan berpengaruh signifikan/positif terhadap kepuasan pengguna website BKD Provinsi Riau.

Pada variabel kualitas kegunaan dengan nilai $\mathrm{t}_{\text {hitung }}>\mathrm{t}_{\text {tabel }}$ yaitu $(2,533)>\mathrm{t}$ tabel $(2,002)$ dan sig $(0,014)<0,05$ dengan demikian $\mathrm{H}_{0}$ ditolak dan $\mathrm{H}_{1}$ diterima.

b. Variabel Kualitas Informasi

Hipotesis variabel kualitas informasi adalah :
Ho : Variabel kualitas informasi tidak berpengaruh signifikan/positif terhadap kepuasan pengguna website BKD Provinsi Riau. $\mathrm{H}_{2}$ : Variabel kualitas informasi berpengaruh signifikan/positif terhadap kepuasan pengguna website BKD Provinsi Riau.

Pada variabel kualitas informasi dengan nilai $\mathrm{t}_{\text {hitung }}>\mathrm{t}_{\text {tabel }}$ yaitu $(4,003)>\mathrm{t}$ tabel $(2,002)$ dan sig $(0,000)<0,05$ dengan demikian $\mathrm{H}_{0}$ ditolak dan $\mathrm{H}_{2}$ diterima.

c. Variabel Kualitas Interaksi Layanan

Hipotesis variabel kualitas interaksi layanan adalah:

Ho : Variabel kualitas interaksi layanan berpengaruh negative terhadap kepuasan pengguna website BKD Provinsi Riau.

$\mathrm{H}_{3}$ : Variabel kualitas interaksi layanan tidak berpengaruh signifikan terhadap kepuasan pengguna website BKD Provinsi Riau.

Pada variabel kualitas interaksi layanan dengan nilai $\mathrm{t}_{\text {hitung }}>\mathrm{t}_{\text {tabel }}$ yaitu $(-0,935)>\mathrm{t}$ tabel $(-$ $2,002)$ dan sig $(0,354)>0,05$ dengan demikian $\mathrm{H}_{0}$ diterima dan $\mathrm{H}_{3}$ ditolak.

\section{D.6 Pembahasan}

1. Pengaruh variabel kualitas kegunaan terhadap kepuasan pengguna website $\mathrm{BKD}$ Provinsi Riau

Berdasarkan hasil pengolahan data didapatkan bahwa kualitas kegunaan memberikan pengaruh yang signifikan sebesar 0,109 terhadap kepuasan pengguna website yang ada di Kantor BKD Provinsi Riau atau dengan kata lain jika kualitas kegunaan meningkat maka kepuasan pengguna website yang ada di Kantor BKD Provinsi Riau akan meningkat dan begitu juga sebaliknya.

2. Pengaruh variabel kualitas informasi terhadap kepuasan pengguna website $\mathrm{BKD}$ Provinsi Riau

Berdasarkan hasil pengolahan data didapatkan bahwa kualitas informasi memberikan pengaruh yang signifikan sebesar 0,1599 terhadap kepuasan pengguna website yang ada di Kantor BKD Provinsi Riau atau dengan kata lain jika kualitas informasi meningkat maka kepuasan pengguna website yang ada di Kantor BKD Provinsi Riau akan meningkat dan begitu juga sebaliknya.

3. Pengaruh variabel kualitas interaksi layanan terhadap kepuasan pengguna website BKD Provinsi Riau

Berdasarkan hasil pengolahan data didapatkan bahwa interaksi layanan tidak memberikan pengaruh yang signifikan terhadap kepuasan pengguna website yang ada di Kantor BKD Provinsi Riau. 


\section{D.7 Dimensi Paling Dominan}

Berdasarkan hasil regresi pada tabel sebelumnya diperoleh bahwa variabel bebas yang memiliki pengaruh paling dominan terhadap kepuasan pengguna yaitu dimensi kualitas informasi sebesar 0,159, sedangkan dimensi kualitas kegunaan sebesar 0,109 dan variabel kualitas interaksi sebesar -0,030. Jadi nilai yang lebih dominan berpengaruh terhadap kepuasan pengguna akan kualitas website adalah variabel $15,9 \%$, variabel kualitas kegunaan $10,9 \%$, dan variabel kualitas interaksi $3 \%$.

\section{E. KESIMPULAN}

Analisa kualitas website Badan Kepegawaian Daerah Provinsi Riau ini menggunakan metode webqual 4.0 maka hasil dari penelitian ini adalah :

1) Hasil dari pengukuran terhadap kepuasan pengguna website ini di Badan Kepegawaian Daerah Provinsi Riau adalah bahwa website ini sudah memuaskan pegawai, berdasarkan diterima dua hipotesis yang diajukan yaitu hipotesis kualitas kegunaan dan kualitas informasi dengan kontribusi variabel terhadap kepuasan sebesar 52,3\%.

2) Adapun hasil hipotesis dari penelitian ini adalah diterimanya atau berpengaruhnya dua variabel dari tiga variabel yang digunakan dalam penelitian ini yaitu, kualitas kegunaan dan kualitas informasi terhadap kepuasan pengguna. Diterimanya keduan variabel tersebut menandakan bahwa kualitas kegunaan Badan Kepegawaian daerah Provinsi Riau sudah sesuai dengan yang diinginkan pegawai, seperti situs website mudah dipelajari, jelas, dan tepat dalam penyusunan tata letak informasi, dan kualitas informasi juga sudah sesuai dengan kepuasaan pegawai, seperti informasinya diberikan jelas, up to date, dan dalam format yang sesuai. Adapun satu hipotesis ditolak yaitu kualitas interaksi pelayanan menandakan bahwa pegawai belum merasa aman, tidak melindungi privasi pegawai, dan tidak yakin dengan informasi yang diberikan.

\section{REFERENSI}

[1] Abbas. Analisa Kepuasan Mahasiswa Terhadap Website Unuversitas Negeri Yogyakarta (UNY). Prosiding SNST ke-4 Tahun 2013.

[2] Arifin, J. SPSS 24 Untuk Penelitian dan Skripsi. Jakarta: PT. Elex Media Komputindo.2007.
[3] Baiti, A. A., Suprapto, \& Rachmadi, A.. Pengukuran Kualitas Layanan Website Dinas Pendidikan Kota Malang Dengan Menggunakan Metode Webqual 4.0 dan IPA. Pengembangan teknologi Informasi dan Ilmu Komputer, 886-887 .2017.

[4] Barnes, S. J., \& Vidgen, R. T. An Integrative Approach To The Assessment Of E-Commerce Quality. Journal of Electronic Commerce Research, VOL. 3, NO. 3, Tahun 2001.

[5] Diana, \& Veronika, N. D. Analisis Kualitas Website Provinsi Bengkulu Menggunakan Metode Webqual 4.0. Jurnal Pseudocode, Volume V Nomor 1, Februari 2018, ISSN 2355-5920, 10.

[6] Ghozali, I. Aplikasi Analisis Multivariate dengan Program IBM SPSS 25. semarang: undip .2018.

[7] Irawan, C. Evaluasi Kualitas Website Pemerintah Daerah Dengan Menggunakan Webqual (Studi Kasus Pada Kabupaten Ogan Ilir). KNTIA, Tahun 2011.

[8] Maslan, A. (n.d.). Pengukuran Kualitas Layanan Website Pemerintah Kota Batam Menggunakan Metode Webqual 4.0. 2 .

[9] Rosania. pengaruh Kegunaan, Kualitas Informasi dan Kualitas Interaksi Layanan Website Perpustakaan Universitas Riau Terhadap Kepuasan Pengguna. Jom FISIP UR, 2016.

[10] Sanjaya, I. Pengukuran Kualitas Layanan Website Kementrian Kominfo Dengan Menggunakan Metode Webqual 4.0. volume 14, No. 1, Juni 2012. 